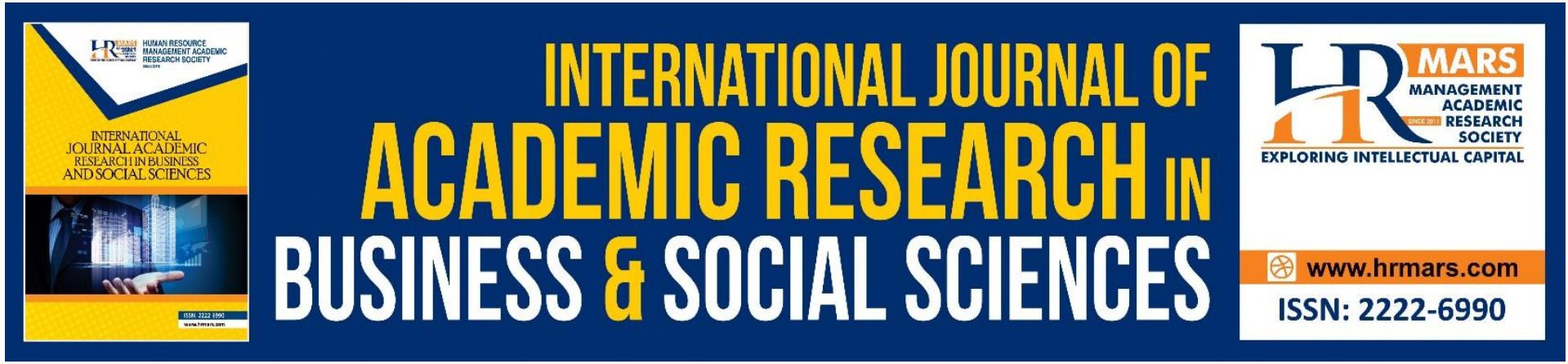

\title{
Determinants of Capital Structure from Shariah-Compliant Firms in Travel, Leisure and Hospitality Sector in Malaysia
}

Amirul Azmin Rohaizan, Mimi Syahirah Abdul Latif, Nor Zulaikha Zulkifli, Wan Nur Syazwina Wan Haswani, Amir Imran Zainoddin

To Link this Article: http://dx.doi.org/10.6007/IJARBSS/v11-i9/10889

DOI:10.6007/IJARBSS/v11-i9/10889

Received: 08 July 2021, Revised: 10 August 2021, Accepted: 31 August 2021

Published Online: 13 September 2021

In-Text Citation: (Rohaizan et al., 2021)

To Cite this Article: Rohaizan, A. A., Latif, M. S. A., Zulkifli, N. Z., Haswani, W. N. S. W., \& Zainoddin, A. I. (2021). Determinants of Capital Structure from Shariah-Compliant Firms in Travel, Leisure and Hospitality Sector in Malaysia. International Journal of Academic Research in Business and Social Sciences, 11(9), 1216-1226.

Copyright: (c) 2021 The Author(s)

Published by Human Resource Management Academic Research Society (www.hrmars.com)

This article is published under the Creative Commons Attribution (CC BY 4.0) license. Anyone may reproduce, distribute, translate and create derivative works of this article (for both commercial and non-commercial purposes), subject to full attribution to the original publication and authors. The full terms of this license may be seen

at: http://creativecommons.org/licences/by/4.0/legalcode

Vol. 11, No. 9, 2021, Pg. 1216 - 1226

http://hrmars.com/index.php/pages/detail/IJARBSS

JOURNAL HOMEPAGE

Full Terms \& Conditions of access and use can be found at http://hrmars.com/index.php/pages/detail/publication-ethics 


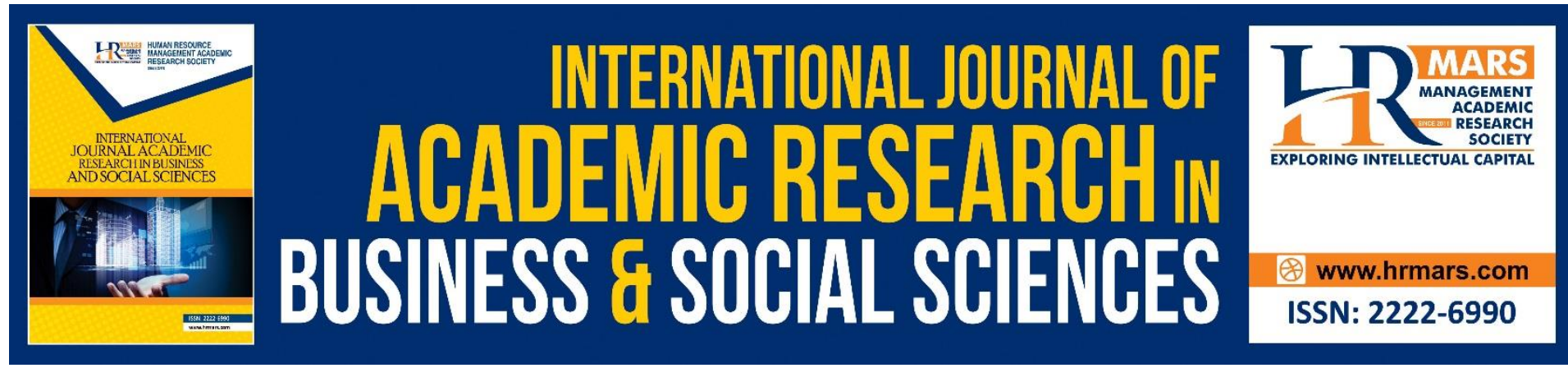

\title{
Determinants of Capital Structure from Shariah- Compliant Firms in Travel, Leisure and Hospitality Sector in Malaysia
}

\author{
Amirul Azmin Rohaizan, Mimi Syahirah Abdul Latif, Nor \\ Zulaikha Zulkifli, Wan Nur Syazwina Wan Haswani, Amir Imran \\ Zainoddin
}

Faculty of Business and Management, Universiti Teknologi MARA Cawangan Johor, Kampus Segamat, 8500 Segamat, Johor, Malaysia

Email: amirimran@uitm.edu.my

\begin{abstract}
Capital structure is essential to a firm as it influences both profit and risk to investors. A balanced capital structure reflects the overall health of the company. As a result, the goal of this research is to look into the capital structures of publicly listed Shariah-compliant firms in the travel, leisure, and hospitality sectors. This study examines 5 publicly listed Shariahcompliant companies in Malaysia throughout 2011 - 2020, and the total number of observations utilized is 50 . Independent variables such as tangible assets, debt-to-equity, and long-term debt are chosen to indicate capital structure. Profitability or performance is identified as the dependent variable of return on assets (ROA) and return on equity (ROE). The majority of the independent factors in Shariah firms showed a substantial association with the firm's success, according to the study's findings. Shariah businesses' asset tangible (TANG) and debt-to-equity (DTE) ratios have a positive connection with return on asset (ROA), but have an insignificant negative link with return on equity (ROE). Long-term debt (LTD), on the other hand, provided a negative insignificant return on asset (ROA) and a positive insignificant return on equity (ROE).
\end{abstract}

Keywords: Capital structure, Return on Assets, Return on Equity, Debt to Equity, Tangible Assets, Long-term Debt

\section{Introduction and Background of Study}

Since the insightful topic by Modigliani and Miller (1958), the body of knowledge has been documenting an extensive effort on capital structure (Haron, 2014). Capital structure research has expanded, and this topic has been widely discussed in corporate finance (Abdul Hadi et al., 2018). Researchers have been particularly interested in the evolution of theory and the validity of contemporary finance theory. Furthermore, one of the essential aspects of corporate finance is capital structure (Kahya et al., 2020)

Corporate finance and capital structure refer to the mix of debt and equity that companies employ to support their operations and development (Cheema et al., 2017). As a result, 
finance managers must choose the optimum financing strategy, whether debt or equity, to increase their company's performance (Daud et al., 2016). According to past research, most businesses choose debt as a source of financing because it provides them with financial flexibility and allows them to run their operations more effectively (Jaafar et al., 2017).

The capital structure represents a financial risk to businesses (Bursa Malaysia, 2021). This research has made many advances to the drivers of the structure of capital in Shariah companies in travel, leisure and hospitality in Malaysia. According to Bursa Malaysia, Travel, Leisure \& Hospitality sector includes companies that provide travel and tourism-related services, including airline, gambling, hotels, restaurants, and recreational benefits. At the time of writing, there are 937 public-listed firms on Bursa Malaysia's MAIN Market, ACE Market, or LEAP Market, with 29 of them falling into the Travel, Leisure \& Hospitality category (Bursa Malaysia, 2021). Out of 29 firms, there are 14 shariah firms.

Shariah is an Islamic law derived from the divine revelation and practice of the prophet Muhammad (SAW), namely, al-Quran and al-Hadith (Adam \& Bakar, 2014). Shariah prohibits the elements of usury (riba), ambiguity in contracts (gharar), and gambling (maysir) in any business activities. These components may be seen in traditional financial operations, which have been labelled as non-shariah compliant businesses. In comparison, Shariah-compliant businesses are expected to adhere to Shariah principles, regulations, and limitations while dealing with their financial sources and funding to improve their performance (Yildirim et al., 2018).

According to Cambridge Dictionary, listed companies can be companies whose shares or security can be traded on a country's primary stock market (Cambridge Dictionary, 2021). Thus, all listed companies in this study issued shares in Bursa Malaysia. According to the Securities Commission Malaysia's Islamic Capital Market report, the total market capitalization of securities listed on Bursa Malaysia in April 2021 is RM 1,838.72 billion (Securities Commission Malaysia, 2021). Market capitalization for shariah compliance public listed companies in the same month is RM 1,264.95 billion. It shows that the Islamic capital market dominates the capital market by $65.96 \%$. As stated in the report, market-to-market growth had also risen from $8.23 \%$ in 2019 to $10.85 \%$ in 2020.

This demonstrated that the Shariah-based financial model is one of the world's fastestgrowing financial sector segments (Abdul Hadi et al., 2018). To be recognised as Shariahcompliant, a business must meet all of the requirements and benchmarks established by the Bank Negara Malaysia (BNM), Shariah Advisory Council (SAC), and Securities Commission Malaysia (SC) (Shahar \& Shahar, 2015). In contrast, conventional finance is mostly a debtbased market that relies on risk transfer, while Islamic finance is asset-based and primarily focused on risk-sharing (Abdul Hadi et al., 2018).

\section{Purpose of Study}

According to Index Mundi, Malaysia's population would have increased to 32,652,083 people by July 2020, up from 31,949,777 in 2019. It comprises $61.3 \%$ Muslims, $19.8 \%$ Buddhists, $9.2 \%$ Christians, 6.3\% Hindus, and 3.4\% others (Malaysia Demographic Profile, 2021). According to statistics, more than half of Malaysians are Muslims. As a result, Muslim entrepreneurship and company must seek and adhere to Shariah principles. Many Muslim individuals and organizations now choose to invest exclusively in Shariah-compliant equities (those that comply with Islamic law) rather than non-compliant businesses. Essentially, Shariahcompliant in making decisions on their source of funding, just like any other regular business that deals with corporate finance (Shahar \& Shahar, 2015a) 
As a result, consumers have high expectations of Shariah-compliant products. Thus, this research will help society since capital structure plays a significant influence on a company's health. The study's relevance is based on the connection between the independent variables Tangible Assets, Debt to equity, and Long-term debt. Return on Assets and Return on Equity are the dependent variables. The findings of this study may assist stakeholders, investors, and shareholders in better understanding the capital structure of Shariah firms in Malaysia's Travel, Leisure, and Hospitality industry. This research will encourage more investors to participate in Travel, Leisure, and Hospitality businesses by providing them with an overview of its risk profile. By referring to this research study, the researchers aim to enhance the understanding of businesses and assist them in making better capital allocation choices to fulfil the business's long-term funding needs and raise its chances of survival during a recession.

\section{Objective}

The main purpose of conducting this research is determinants of capital structure towards Shariah Compliant in Travel, Leisure \& Hospitality sector in Malaysia.

I. To investigate the relationship between Tangible Asset (TANG) towards Shariah Compliant in Travel, Leisure \& Hospitality sector in Malaysia.

II. To investigate the relationship between Debts to Equity (DTE) towards Shariah Compliant in Travel, Leisure \& Hospitality sector in Malaysia.

III To investigate the relationship between Long-term debts (LTD) towards Shariah Compliant in Travel, Leisure \& Hospitality sector in Malaysia.

\section{Literature Review}

One of the profitability ratios is return on assets (ROA) (Rosikah et al, 2018). Return on investment, or ROA, is a financial statistic that indicates how well a business utilizes its assets to generate revenue (Cheema et al., 2017). Meanwhile, the return on equity (ROE) is a profitability measure that indicates how profitable a business is with its share capital (Rosikah et al., 2018). Some factors increase or decrease the dependent variable: tangible assets, longterm debt, and debt-to-equity.

The purpose of the study by Gharaibeh \& Bani Khaled (2020), aimed to investigate the influence of financial characteristics and capital structure on the profitability of all 46 Amman Stock Exchange-listed service businesses from 2014 to 2018. Utilizing pecking order theory, this researcher applies fixed and random effects models to panel data variables, with tangible assets and the debt-to-equity ratio serving as independent variables used to assess profitability (ROA and ROE). According to the findings, tangible assets have a negative and significant influence on profitability.

Jaishi (2020) investigates the link between capital structure and financial performance of 14 Nepalese insurance companies. One of the independent variables is asset tangibility, while one of the dependent variables is asset return. The findings indicate that asset tangibility has a positive and significant impact on the financial performance and return on assets of Nepal insurance companies.

According to Cheema et al (2017), they examined a population from the Technology and Communication industry using correlation and Ordinary Least Square Regression, which comprises seven businesses, three of which are Shariah-compliant, four of which are not. The variables are gathered for a total of seven years, from 2009 to 2015. Shariah-compliant firms have a positive but insignificant influence on the average long-term debt ratio of ROE. The 
results show that the long-term debt ratio (LTD) is positive and that the performance measures ROA and ROE are inconsequential.

Nadeem et al (2015) tried to measure the link between debt and profitability in the Pakistani cement business between 2008 and 2012. Return on equity (ROE) and return on assets (ROA) are two financial measures used to evaluate a company's performance. Long-term debt (LTD) is one of the leverage factors. Long-term debt (LTD) was discovered to have a positive and substantial association with Return on Equity (ROE) and Return on Assets (ROA).

Basit \& Irwan, (2017) investigate the impact of capital structure in Bursa Malaysia Exchangelisted businesses on industrial product by choosing 50 industrial organisations from 2011 to 2015. Debt to Equity and Return on Assets are utilised as independent variables, whereas Return on Equity is used as a dependent variable. According to the results, the debt-to-equity ratio had a significant negative effect on both dependent variables (i.e., ROE and ROA).

Zelalem, D., (2020) investigate the financing decision function of corporate finance is in charge of finding the optimal financing mix or capital structure for a firm in order to maximise its value or wealth. The major objective of this research is to investigate the impact of financial leverage on the financial performance of Ethiopian commercial banks from 2008 to 2017. The debt-to-equity ratio is used to describe financial leverage, whereas the return on assets and return on equity are used to define financial performance. According to the data, the debtto-equity ratio has a significant and positive relationship with the return on assets and equity.

\section{Methodology}

\section{Types of Investigation}

There are two types of research: causal research and correlational research. This type of study is known as correlational analysis since the relationships between the variables are connected. The goal of this study is to evaluate the Return on Assets (ROA) and Return on Equity (ROE) of Shariah-compliant companies in the Travel, Leisure, and Hospitality subsectors to determine the influence of profitability on capital structure.

\section{Sampling Technique}

There are two kinds of sampling methods. Probability sampling and non-probability sampling are the two types of sampling techniques. Probability sampling uses statistical theory to randomly choose a subset of a large population to ascertain if all their responses are acceptable for the whole population. In comparison, non-probability sampling is less expensive and often more expedient (Etikan, 2016).

Due to constraints in terms of time, information, and list that could be acquired from the population, this study did not use the Probability Sampling Technique, which requires the researcher to apply a technique based on probability theory (Acharya et al., 2013). Rather than that, in this investigation, non-Probability sampling was utilised. Convenience sampling was selected from the Non-Probability Sampling category to facilitate sample availability, timeliness, and cost-effectiveness. Convenience sampling was used since it is impossible to include every subject due to the population's size. Thus, the primary aim of this sample is to gather data from readily available participants (Etikan, 2016). 


\section{Shariah-compliant companies (2011 - 2020)}

1. Advance Synergy Berhad: ASB (1481)

2. Avillion Berhad: AVI (8885)

3. AirAsia Group Berhad: AIRASIA (5099)

4. Konsortium Transnational Berhad: KTB (4847)

5. Pan Malaysia Holdings: PMHLDG (1287)

\section{Source: Bursa Malaysia}

Table 1: List of Samples Taken from Travel, Leisure and Hospitality Sectors, along with each stock code

\section{Data Collection Method}

The study is performed via the use of secondary data collected from an online database. The research examined the capital structure of Shariah-compliant Travel, Leisure, and Hospitality businesses. Five businesses were selected from this, and the companies were listed on Bursa Malaysia. Numerous techniques are utilized to establish the connection between independent and dependent variables, including estimating long-term debt, tangible assets, and debt to equity (i.e., independent variables) furthermore, ROA and ROE (i.e., dependent variables). Secondary data were gathered from the company's annual reports between 2011 and 2020.

\section{Theoretical Framework}

The theoretical framework aims to understand better the outputs of selected dependent variables. Return on Assets (ROA) and Return on Equity (ROE) are indicators of a company's performance and how it is influenced by external factors. Tangible Assets, Debt to Equity, and Long-term Debt as independent variables in the capital structure in shariah-compliant travel, leisure, and hospitality industries.

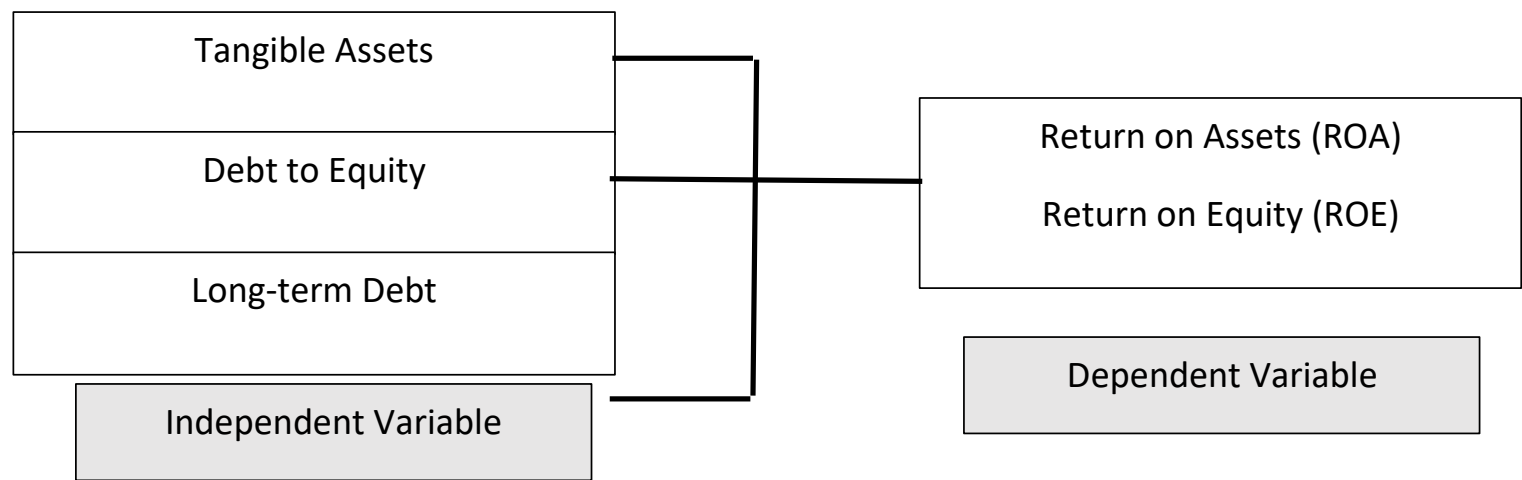

Figure 1: Theoretical Framework 


\section{Result of the Study \\ Return on Asset (ROA) in Shariah Firm}

\begin{tabular}{|l|l|l|}
\hline Variables & P-value & Results \\
\hline Asset tangible (TANG) & 0.0066 & Significant; reject the null hypothesis (H0) \\
\hline Debt-to equity (DTE) & 1.001977 & Significant; reject the null hypothesis (H0) \\
\hline Long-term debt (LTD) & -2.508459 & Not significant; do not reject the null hypothesis (H0) \\
\hline
\end{tabular}

Table 2: Summary of the Result Regression for Return on Asset (ROA) Variable on Shariah Firms

$Y=$ Return on Equity, TANG = Tangible Asset, DTE = Debt-to-Equity, LTD = Long-term debt Based on the result, overall significant $f$-test of this model for the independent variables for the tangible asset (TANG), debt-to-equity (DTE), and long-term debt (LTD) significant relationship with 0.000027 of $P$-value to the return on assets (ROA) of companies since (Ftest $P$-Value $<0.05)$. This means that the tangible asset (TANG), debt-to-equity (DTE), and long-term debt (LTD) variables do have an impact on the return on asset (ROA) of the company. This indicates that the chosen model was excellent.

Still, the other vital index to check is adjusted R2 for the extent of the interpretation of the suggested model to (ROA). The explained sum of squares to the total sum of squares ratio is $R^{2}$. The $R^{2}$ value indicates how well the computed regression equation matches the sample data. The $\mathrm{R}^{2}$ value of 0.401679 demonstrates that the variability of the independent variable, tangible asset, debt-to-equity, and long-term debt, explains $40.16 \%$ of the variation in the dependent variable, Return on Asset (ROA). In contrast, other factors not included in the research account for the remaining $59.84 \%$. The adjusted $R 2$, on the other hand, is 0.362658 , which is less than the R2. This shows that the regression model is well-fitting and may assess a company's success (ROA).

According to the Panel Least Square Regression findings, the $p$-value for the tangible asset (TANG) is 0.0066 , with a $95 \%$ confidence interval. Because the $p$-value is less than 0.05 , it shows that the tangible asset is significant. Tangible assets (TANG) have a beta coefficient of positive 1.77E-06/0.00000177, which implies that a 1-unit growth in the tangible asset will boost firm performance (ROA) 1.77E-06/0.00000177 unit. This indicates that tangible assets have a beneficial effect on business performance (ROA); as a result, businesses that want to enhance their return on assets might expand their tangible assets (Jaishi, 2020). The findings support by Zrar et al (2017) that there is a substantial and positive link between tangible assets and Return on Asset (ROA) as a performance measure. A research by Ahmed \& Bhuyan, (2020), found a positive link between tangible assets and return on assets (ROA), which validated this conclusion.

Thus, the debt-to-equity (DTE) ratio has a positive and substantial relationship with the company's return on asset (ROA). It illustrates that a one-unit increase in debt-to-equity (DTE) results in a one-unit increase in the company's return on asset (ROA). This was also supported by a research, which discovered that debt-to-equity (DTE) had a significant positive effect on Return on Asset (ROA) (Zelalem, 2020).

Furthermore, long-term debt (LTD) has statistically insignificant with the return on asset (ROA) of the company's performance. At the $95 \%$ confidence interval, the result is 0.8044 with a negative coefficient of -2.508459 . According to the beta coefficient of negative - 
2.508459 for long-term debt (LTD), the company's performance (ROA) will decrease by 2.508459 units for every 1 unit increase in long-term debt (LTD), assuming all other factors remain constant. The firm's reliance on long-term loans causes further distortions and raises its financing costs, lowering profitability (Njagi Kirmi, 2017). The result supports by Njagi Kirmi, (2017) that there is no substantial and negative connection between long-term debt (LTD) and return on asset (ROA) to assess a company's performance.

\section{Return on Equity (ROE) in Shariah Firm}

\begin{tabular}{|l|l|l|}
\hline Variables & P-value & Results \\
\hline Asset tangible (TANG) & 0.6842 & Not significant; do not reject the null hypothesis (H0) \\
\hline Debt-to equity (DTE) & 0.0110 & Significant; reject the null hypothesis (HO) \\
\hline Long-term debt (LTD) & 0.5549 & Not significant; do not reject the null hypothesis (H0) \\
\hline
\end{tabular}

Table 3: Summary of the result Regression for Return on Equity (ROE) Variable on Shariah Firms

$Y=$ Return on equity, TANG = Asset Tangible, DTE= Debt-to-equity, LTD= Long-term debt

Table 3 shows the panel Least Square Regression for return on equity (ROE) in 5 Shariah companies over a 10-year period from 2011 to 2020, which is explained by the independent variables of asset tangible (TANG) debt-to-equity (DTE), and long-term debt (LTD).

The F-statistic value is 2.612388, and the F-statistic P-value is 0.062542 . There is an insignificant relationship f-test of this model for the independent variable for the tangible asset (TANG), debt-to-equity (DTE) and long-term debt (LTD) with the return on equity (ROE) of the Shariah firms since (F-value P-value $>0.005$ ). This means that the tangible asset (TANG), debt-to-equity (DTE), and long-term debt (LTD) variables do not have an impact on the return on equity (ROE) in Shariah firms.

$R$-squared $\left(R^{2}\right)$ is a statistical metric that indicates the proportion of variation explained by an independent variable in a regression model for a dependent variable for Shariah firms. The Rsquared value indicates how near the data is to the fitted regression line. The $R^{2}$ result of 0.145572 implies that dependent variables, return on equity (ROE) for Shariah Company, explains $14.56 \%$ of the variation. Other factors not included in the research accounted for the remaining $85.44 \%$. Furthermore, we may reject the null hypothesis when the $p$-value of the F-statistic is 0.0000 , which is used to evaluate the overall significance of the regression model. The adjusted $R^{2}$ is 0.089848 , which is somewhat less than the $R^{2}$. This indicates that the regression model is well-fitting and may assess Shariah firm's success, the return on equity (ROE).

According to the Panel Least Square Regression result, the $p$-value for asset tangible (TANG) in Shariah company is 0.6842 . It shows that TANG is negative insignificance since the level of $\mathrm{p}$-value is more than 0.05 with a beta coefficient of a negative $1.45 \mathrm{E}-05 / 0.00000145$ point from return on equity (ROE), which means that a decrease in $1 \%$ of ROE will affect TANG to decrease by $1.45 \mathrm{E}-05 / 0.00000145$ point. As a result, it interprets that asset tangible (TANG) do not influence return on equity (ROE). As a consequence, managers will receive crucial insight into the fact that a high asset tangible (TANG) does not necessarily imply a high return (Anuar et al., 2021). The results are similar with previous study Anuar et al (2021) which shows a negative and insignificant link between asset tangible (TANG) and return on equity (ROE). Next, in Shariah businesses, debt-to-equity (DTE) has a positive and substantial association with return on equity (ROE). It shows that an increase of $1 \%$ of debt-to-equity (DTE) will 
increase return on equity (ROE) by 54.44780 points in the firm's performance, which is defined as the return on equity (ROE). The results are consistent with the study in the past which is Efendi et al (2019), DTE has a significant positive impact on performance as measured by return on equity (ROE). Meanwhile, the research study by Khalifa Tailab, (2014) is contrasted with our result, which is the positive and insignificant relationship between debtto-equity (DTE) and return on equity (ROE).

Furthermore, long-term debt (LTD) has a statistically good but negligible association with a company's return on equity (ROE). The result shows 0.5549 at a $95 \%$ confidence interval and a positive 339.8008-point coefficient. The beta coefficient of positive 339.8008 for long-term debt (LTD), the Shariah firm's performance of Return on Equity (ROE) will increase by 339.8008 points for every 1 unit in long-term debt (LTD) (Erdoğan, 2014). This indicates that using a low level of debt might affect a company's return on equity. This finding is consistent with empirical findings from Erdoğan, (2014) that long-term debt (LTD) has a favourable but insignificant impact on financial performance, as measured by return on equity (ROE).

\begin{tabular}{|c|c|c|c|c|}
\hline $\begin{array}{c}\text { The } \\
\text { Relationships }\end{array}$ & Coefficient & T-Statistic & P-Value & Notes \\
\hline TANG - ROA & $1.77 \mathrm{E}-06$ & 2.842735 & 0.0066 & Significant \\
\hline TANG - ROE & $-1.45 \mathrm{E}-05$ & -0.409286 & 0.6842 & $\begin{array}{c}\text { Not } \\
\text { Significant }\end{array}$ \\
\hline DTE - ROA & 1.001977 & 2.768063 & 1.001977 & Significant \\
\hline DTE - ROE & 54.44780 & 2.651489 & 0.0110 & Significant \\
\hline LTD - ROA & -2.508459 & -0.249118 & -2.50846 & $\begin{array}{c}\text { Not } \\
\text { Significant }\end{array}$ \\
\hline LTD - ROE & 339.8008 & 0.594859 & 0.5549 & $\begin{array}{c}\text { Not } \\
\text { Significant }\end{array}$ \\
\hline
\end{tabular}

Table 4: Summary of Overall Result

\section{Conclusion}

Asset tangible (TANG) for shariah companies exhibit a strong positive connection with return on asset (ROA), but an insignificant negative relationship with return on equity (ROE). As a result, the literature backs up our findings by Zrar et al., (2017) that have a substantial positive link between tangible asset (TANG) and return on asset (ROA); meanwhile, Anuar et al., (2021) have a negligible inverse connection with return on equity (ROE). Therefore, the larger the tangible asset value, the more stable the company is because these assets may be liquidated and turned into cash when the company needs it (Md-Yusuf, 2017).

In addition, debt-to-equity (DTE) Shariah Company has a substantial positive return on asset (ROA), which is the same result as Zelalem (2020) but shows a negative insignificant with return on equity (ROE), that also supported by the literature (Efendi et al., 2019). Therefore, the long-term debt ratio is a financial leverage ratio that measures how much long-term debt is used to support a company's assets (Cheema et al., 2017).

The last independent variable, long-term debt (LTD) for Shariah firms, shows a negative insignificant with return on asset (ROA); meanwhile, a positive insignificant with return on equity (ROE). The study from Njagi Kirmi, (2017) shows an insignificant negative relationship towards return on asset (ROA) and Erdoğan, (2014) shows a positive insignificant with return on equity (ROE). Therefore, the higher the ratio, the greater the company's capacity to pay interest and the better its chances of getting a loan (Efendi et al., 2019). 
The asset tangible insignificant with return on equity shows that managers will gain vital insight into the fact that a high asset tangible does not always imply a high return Anuar et al (2021). Furthermore, the long-term debt insignificant relationship with return on assets causes further distortions. Kirmi (2017), it raises its financing costs, lowering profitability and the long-term debt insignificant relationship with return on equity. Erdoğan (2014) mention that using a low level of debt might affect company's return on equity.

We can conclude that most of the independent variables in Shariah firms have a significant relationship with the firm's performance: the return on asset and return on equity. According to (Mohd-Sanusi et al., 2015), ethical investments for Muslims in Malaysia are those made in financial goods permitted by Islamic law Shariah. The Islamic Capital Market (ICM) is created in Malaysia due to increased awareness of Shariah-approved goods (Securities Commission). The ICM refers to a market where activities are conducted out that does not contradict Muslim conscience or Islam's faith. They also said that financial services investments must not include riba, gharar (uncertainties), or the manufacture or sale of non-halal products (Securities Commission Malaysia, 2021).

\section{References}

Abdul Hadi, A. R., Rehan, R., Zainudin, Z., \& Hussain, H. I. (2018). Capital structure determinants of shariah and non-shariah companies at bursa Malaysia. Opcion.

Acharya, A. S., Prakash, A., Saxena, P., \& Nigam, A. (2013). Sampling: why and how of it? Indian Journal of Medical Specialities. https://doi.org/10.7713/ijms.2013.0032

Adam, N. L., \& Bakar, N. A. (2014). Shariah Screening Process in Malaysia. Procedia - Social and Behavioral Sciences. https://doi.org/10.1016/j.sbspro.2014.01.1113

Ahmed, R., \& Bhuyan, R. (2020). Capital Structure and Firm Performance in Australian Service Sector Firms: A Panel Data Analysis. Journal of Risk and Financial Management, 13(9), 214. https://doi.org/10.3390/jrfm13090214

Anuar, R. Bin, Jais, M. Bin, \& Tinggi, M. (2021). The Impact of Non-Current Assets on the Performance of Firms in Malaysian Construction Sector. International Journal of Academic Research in Accounting Finance and Management Sciences, 11(1), 1-. https://doi.org/10.6007/IJARAFMS

Basit, A., \& Irwan, N. F. (2017). THE IMPACT OF CAPITAL STRUCTURE ON FIRMS PERFORMANCE : EVIDENCE FROM MALAYSIAN INDUSTRIAL SECTOR - A CASE BASED APPROACH. 5(2), 131-148.

Cheema, M. H., Mahboob, H., Farooq, N., \& Yousaf, A. (2017). Capital Structure Impact on Financial Performance of Sharia and Non-Sharia Complaint Companies of Pakistan Stock Exchange. International Journal of Business and Management Review.

Daud, W. M. N. W., Norwani, N. M., Mansor, A. A., \& Endut, W. A. (2016). Does financing decision influence corporate performance in Malaysia? International Journal of Economics and Financial Issues.

Efendi, A., Putri, L. P., \& Dungga, S. (2019). The Effect of Debt to Equity Ratio and Total Asset Turnover on Return on Equity in Automotive Companies and Components in Indonesia. https://doi.org/10.2991/icame-18.2019.20

Erdoğan, S. (2014). The effect of capital structure on profitability: An empirical analysis. In Handbook of Research on Developing Sustainable Value in Economics, Finance, and Marketing (Vol. 7, Issue 9, pp. 307-323). https://doi.org/10.4018/978-1-4666-66351.ch018

Etikan, I. (2016). Comparison of Convenience Sampling and Purposive Sampling. American 
Journal of Theoretical and Applied Statistics.

https://doi.org/10.11648/j.ajtas.20160501.11

Gharaibeh, O. K., \& Bani Khaled, M. H. (2020). "Determinants of profitability in Jordanian services companies." In Investment Management and Financial Innovations. https://doi.org/10.21511/imfi.17(1).2020.24

Haron, R. (2014). Key factors influencing target capital structure of property firms in Malaysia. Asian Social Science. https://doi.org/10.5539/ass.v10n3p62

Jaafar, M. N., Muhamat, A. A., Ahmad, I., \& Syed Alwi, S. F. (2017). Determinants of capital structure: Empirical evidence from Shariah compliant plantation firms in Malaysia. Journal of Emerging Economies and Islamic Research.

https://doi.org/10.24191/jeeir.v5i4.6235

Jaishi. (2020). Capital Structure and its Impact on Financial Performance in Insurance Companies of Nepal. Journal of Nepalese Business Studies.

https://doi.org/10.3126/jnbs.v13i1.34708

Kahya, E. H., Ersen, H. Y., Ekinci, C., Taş, O., \& Simsek, K. D. (2020). Determinants of capital structure for firms in an Islamic equity index: comparing developed and developing countries. Journal of Capital Markets Studies. https://doi.org/10.1108/jcms-07-20200023

Tailab, K. M. M. (2014). The Effect of Capital Structure on Profitability of Energy American Firms. In International Journal of Business and Management Invention ISSN.

Md-Yusuf, M. (2017). Capital Structure Determinants of SME Shariah Compliant Companies. https://doi.org/10.2991/icbmr-17.2017.16

Mohd-Sanusi, Z., Ismail, R., Hudayati, A., \& Harjito, D. A. (2015). Screening process of Shariahcompliant companies: The relevance of financial risk management. International Journal of Economics and Management.

Nadeem, M., Ahmad, R., Ahmed, A., Ahmad, N., \& Batool, R. S. (2015). The Effect of Leverage on Financial Health of the Firms: A Study from Cement Industry of Pakistan. Industrial Engineering Letters, 5(5), 123-127.

Kirmi, N. P. (2017). Relationship Between Capital Structure and Profitability, Evidence From Listed Energy and Petroleum Companies Listed in Nairobi Securities Exchange. Journal of Investment and Management, 6(5), 97. https://doi.org/10.11648/j.jim.20170605.11

Yildirim, R., Masih, M., \& Bacha, O. I. (2018). Determinants of capital structure: evidence from Shari'ah compliant and non-compliant firms. Pacific Basin Finance Journal. https://doi.org/10.1016/j.pacfin.2018.06.008

Zelalem, D. (2020). The Impact of Financial Leverage on the Performance of Commercial Banks: Evidence from Selected Commercial Banks in Ethiopia. International Journal of Accounting, Finance and Risk Management. https://doi.org/10.11648/j.ijafrm.20200501.16

Zrar, S., Bilbas, A., Taher, W., \& Asst, S. (2017). the Impact of Capital Structure on the Firm'S Profitability: an Empirical Study on Investment Firms in the Housing Sector in Iraq Kurdistan Region for the Period (2007-2016). International Journal of Economics, Commerce and Management United Kingdom. 